\title{
The Direct Horizontal Effect of EU Fundamental Rights
}

\author{
ECJ 17 April 2018, Case C-414/16, Vera Egenberger v Evangelisches \\ Werk für Diakonie und Entwicklung e.V. and ECJ 11 September \\ 2018, Case C-68/17, IR v JQ
}

Aurelia Colombi Ciacchi*

\section{INTRODUCTION}

2018 was a glorious year for scholars who, like myself, have long been advocates of the direct horizontal effect of (EU) fundamental rights. In four judgments Egenberger, ${ }^{1} I R$ v JQ, ${ }^{2}$ Bauer, ${ }^{3}$ and Max Planck $^{4}$ - the European Court of Justice definitively established the direct effect of Article 21, Article 31(2), and Article 47 of the Charter of Fundamental Rights of the EU (hereafter: The Charter) in the adjudication of litigations between private parties.

The present paper is a commentary on Egenberger and $I R \mathrm{v} J Q$. Both cases deal with the religion-based discrimination of (potential) employees by a church-based

*Professor of Law and Governance, the University of Groningen, The Netherlands.

${ }^{1}$ ECJ 17 April 2018, Case C-414/16, Vera Egenberger v Evangelisches Werk für Diakonie und Entwicklung e.V.

${ }^{2} \mathrm{ECJ} 11$ September 2018, Case C-68/17, IR v JQ.

${ }^{3}$ ECJ 6 November 2018, Joined Cases C-569/16 and C-570/16, Stadt Wuppertal and Volker Willmeroth als Inhaber der TWI Technische Wartung und Instandsetzung Volker Willmeroth e.K. $\mathrm{v}$ Maria Elisabeth Bauer and Martina Broßonn. For a comment on this judgment see, in this issue, the case note on Bauer et al., E. Frantziou, '(Most of) The Charter of Fundamental Rights Is Horizontally Applicable’, 15 EuConst (2019) p. 306.

${ }^{4}$ ECJ 6 November 2018, Case C-684/16, Max-Planck-Gesellschaft zur Förderung der Wissenschaften e.V. v Tetsuji Shimizu.

European Constitutional Law Review, 15: 294-305, 2019

(C) The Author(s) 2019. This is an Open Access article, distributed under the terms of the Creative Commons Attribution-NonCommercial-NoDerivatives licence (http://creativecommons.org/licenses/by$n c-n d / 4.0 /)$, which permits non-commercial re-use, distribution, and reproduction in any medium, provided the original work is unaltered and is properly cited. The written permission of Cambridge University Press must be obtained for commercial re-use or in order to create a derivative work. doi:10.1017/S1574019619000154 
employer. And, ironically, both cases come from Germany, where the legal culture over the last 40 years has been quite hostile towards the direct horizontal effect of fundamental rights. ${ }^{5}$

\section{THE FACTS IN BOTH LITIGATIONS}

In the first case, a job applicant - Ms Vera Egenberger - had allegedly been discriminated against because she did not belong to any religious denomination. The employer, Evangelisches Werk, had explicitly stated in the job advertisement that membership in a Protestant church or a church affiliated with the Working Group of Christian Churches in Germany was required, even though the job in question arguably had very little to do with churches. Ironically, the position mainly consisted of writing reports on German efforts to combat discrimination in the framework of the UN Convention on the Elimination of All Forms of Racial Discrimination.

The second case concerned a conflict between JQ, a physician, and his employer, IR, a private organisation dependent on the Catholic Church. JQ was divorced; he subsequently remarried in a civil ceremony without having his first (Catholic) marriage annulled by a church tribunal. IR, therefore, terminated the employment contract.

In both cases, an employee was claiming that the employer's actions were not compatible with the prohibition of discrimination in the German General Law on Equal Treatment (Allgemeines Gleichbehandlungsgesetz) as interpreted in accordance with EU law. And, in both cases, German labour courts had already (partly) decided in favour of the employee at the phase of litigation preceding the reference for a preliminary ruling.

For Ms Egenberger, although the labour court of first instance had held that she was a victim of discrimination, it ordered that compensation of no more than $€ 1957.73$ be paid. Ms Egenberger's further appeals were mainly motivated by her wish to be awarded a considerably greater amount. The German Federal Labour Court (Bundesarbeitsgericht) referred the case to the European Court of Justice, since it considered that the outcome of the dispute in the main proceedings depended on whether the fact that the employer had made a differentiation based on church membership was lawful under the German General Law on Equal Treatment, which had to be interpreted in conformity with EU law.

JQ's litigation against IR had gone on for nine years before the Court of Justice passed judgment. The discrimination alleged by JQ and confirmed by the labour courts was, paradoxically, based on the fact that JQ adhered to the same faith as his employer. Indeed, JQ was dismissed because he, a Roman Catholic, had remarried in a civil union without annulling his Catholic marriage beforehand before a church tribunal. This would not have happened to an employee who

${ }^{5}$ See text between n. 31 and n. 41 below. 
was, for instance, Protestant or religiously unaffiliated. Thus, JQ alleged and the labour courts acknowledged that discrimination had taken place, arguing that IR would not have dismissed a non-Roman Catholic employee occupying the same post as JQ in the event he or she remarried.

JQ's dismissal was deemed unlawful by each labour court involved, including the German Federal Labour Court. In a last-ditch attempt to prevail, IR filed a constitutional complaint with the German Federal Constitutional Court (Bundesverfassungsgericht). The complaint was successful: the Constitutional Court annulled the judgment of the Federal Labour Court because it had not sufficiently taken into account the special position of churches under German constitutional law. The Federal Labour Court had to issue a new judgment on the same litigation. At this point, the Federal Labour Court - expressing doubts about the EU law-compatibility of the Constitutional Court's broad interpretation of the churches' freedoms - referred the case to the European Court of Justice.

\section{The BACKground OF THE DISPUTES: THE CLASH BETWEEN EU NON- DISCRIMINATION LAW AND THE EXTREME 'CHURCH-FRIENDLINESS' OF GERMAN LAW}

In both Egenberger and $I R \mathrm{v} J Q$, the root of the problem was the extremely 'church-friendly' exemptions allowed by the German legislator in the implementation of Directive 2000/78. Certain exemptions are, in fact, allowed by Article 4(2) of this Directive, according to which:

$\ldots$ in the case of occupational activities within churches and other public or private organisations the ethos of which is based on religion or belief, a difference of treatment based on a person's religion or belief shall not constitute discrimination where, by reason of the nature of these activities or of the context in which they are carried out, a person's religion or belief constitute a genuine, legitimate and justified occupational requirement, having regard to the organisation's ethos. This difference of treatment shall be implemented taking account of Member States' constitutional provisions and principles, as well as the general principles of Community law, and should not justify discrimination on another ground. ${ }^{6}$

The German legislator went very far in allowing exemptions for church-based employers. Paragraph 9 of the General Law on Equal Treatment, which implements Article 4(2) of the Directive, states in its first subparagraph (the stipulation relevant to the Egenberger dispute) that:

... a difference of treatment on grounds of religion or belief in connection with employment by religious societies, institutions affiliated to them regardless of their

${ }^{6}$ Emphasis added. 
legal form, or associations which devote themselves to the communal nurture of a religion or belief shall also be permitted if a particular religion or belief constitutes a justified occupational requirement, having regard to the self-perception of the religious society or association concerned, in view of its right of self-determination or because of the type of activity.

Also, the second subparagraph of Paragraph 9 of the General Law on Equal Treatment (the stipulation relevant to the $I R \mathrm{v} J Q$ dispute) focuses on the self-perception of religious communities. It states:

The prohibition of a difference of treatment on grounds of religion or belief shall not affect the right of the religious communities (...), institutions affiliated to them, regardless of their legal form, or associations that devote themselves to the communal nurture of a religion or belief, to require their employees to act in good faith and with loyalty in accordance with their self-perception. ${ }^{8}$

There is a subtle yet very powerful shift in perspective between the wording of Article 4(2) of the Directive and Paragraph 9 of the General Law on Equal Treatment. The Directive sets an objective limit to the justification of a difference in treatment based on religion or belief: a person's religion or belief must objectively constitute a genuine, legitimate and justified occupational requirement, by reason of the nature of these activities or of the context in which they are carried out, having regard to the organisation's ethos. The perspective is that of an independent observer. On the contrary, the wording of Paragraph 9 of the General Law on Equal Treatment adopts a subjective perspective. It allows to answer the questions of whether a given religion or belief constitutes a justified occupational requirement, and whether an employee acts in good faith and with loyalty, by focusing on the 'self-perception' of the religious organisation itself, given its right of self-determination. This means, in practice, that a religious organisation itself may to a large extent authoritatively determine whether a difference in treatment based on religion or belief made by an entity affiliated with that organisation is justified. This makes it very difficult for German courts to review the lawfulness of acts of religious organisations when those acts discriminate workers based on their religion or beliefs.?

${ }^{7}$ Emphasis added.

${ }^{8}$ Emphasis added.

${ }^{9}$ The German Federal Constitutional Court (Bundesverfassungsgericht) limits judicial review in such cases to an assessment of the plausibility of the determination by the religious organisation of whether the activities in question are connected to its ethos in a way that religious affiliation is required of the employee. See the Bundesverfassungsgericht's decision in the IR v JQ case: BVerfG 22 October 2014, 2 BvR 661/12, ECLI:DE:BVerfG:2014:rs20141022.2bvr066112. With regard to Egenberger see B. Göpfert, 'EuGH entscheidet maßgeblich zum Kirchenarbeitsrecht ('Egenberger')', Arbeitsrecht. Weltweit, 17 April 2018, 〈www.arbeitsrecht-weltweit.de/2018/04/ 17/eugh-entscheidet-massgeblich-zum-kirchenarbeitsrecht-egenberger/〉, visited 1 May 2019. 
The questions referred to the Court of Justice in both Egenberger and $I R \mathrm{v} J Q$ ask first and foremost whether Article 4(2) of the Directive is compatible with the aforementioned subjective perspective, and if not, how that article should be interpreted.

\section{THE FIRST REVOLUTION: CIVIL COURTS MAY REVIEW THE SUBSTANCE OF DECISIONS OF RELIGIOUS ORGANISATIONS}

In both cases, the Court of Justice clearly rejected the subjective perspective defended by both the religious organisations and the German government, requiring that Article 4(2) be interpreted from an objective perspective. And in both cases, the Court gave very wise answers which assigned national courts the task of determining the delicate balance between worker protection and discrimination based on religion or belief on the one hand, and the autonomy of religious organisations on the other.

In Egenberger, the Court first explained that Article 4(2) sets out the criteria that must be taken into account in the balancing exercise performed when two competing fundamental rights are in play: in this case, the fundamental right of workers not to be discriminated against and the right of autonomy of organisations whose ethos is based on religion or belief. In the event of a dispute, 'it must be possible for the balancing exercise to be subject if need be of review by an independent authority, and ultimately by a national court'. ${ }^{10}$

The Court of Justice reached this result, inter alia, by interpreting Article 4(2) of the Directive in the light of Article 47 of the Charter. The Court clarified that it must be possible for an assertion of an organisation whose ethos is based on religion or belief to be the subject of 'effective judicial review by which it can be ensured that the criteria set out in Article 4(2) of that directive are satisfied in the particular case'. ${ }^{11}$

In Egenberger, the Court explicitly required that an objective perspective be adopted for the interpretation of Article 4(2) of the Directive. First, this provision 'must be interpreted as meaning that the genuine, legitimate and justified occupational requirement it refers to is a requirement that is necessary and objectively dictated (...)'. Second, the occupational requirement must comply with the principle of proportionality. ${ }^{12}$

See also L. Lourenço, 'Religion, discrimination and the EU general principles' gospel: Egenberger', 56 Common Market Law Review (2019) p. 193 at p. 195.

${ }^{10}$ Egenberger, paras. 52-53.

${ }^{11}$ Ibid., para. 59.

${ }^{12}$ Ibid., para. 69. On this proportionality requirement, see R. McCrea, 'Salvation outside the church? The ECJ rules on religious discrimination in employment', EU Law Analysis, 18 April 2018, available at 〈eulawanalysis.blogspot.com/2018/09/religious-discrimination-at-work-can.html〉, visited 29 April 2019. See also Lourenço, supra n. 9, p. 199. 
Likewise, in $I R \mathrm{v} J Q$, the Court rejected the subjective perspective defended by IR and the German government and required an objective perspective as well as effective judicial review of the decisions of religious organisations. In $I R \mathrm{v} J Q$, the Court clearly stated that an organisation whose ethos is based on religion or belief 'cannot decide to subject its employees performing managerial duties to a requirement to act in good faith and with loyalty to that ethos that differs according to the faith or lack of faith of such employees, without that decision being subject, where appropriate, to effective judicial review to ensure that it fulfils the criteria laid down in Article 4(2)' of the Directive. ${ }^{13}$

The abovementioned principles stated by the Court in Egenberger and $I R \vee J Q$ entail that Paragraphs 9(1) and (2) of the General Law on equal treatment are not, as such, incompatible with EU law. However, national courts have to interpret and apply them in conformity with the Directive and strike a fair balance between competing fundamental rights. The requirements laid down in Article 4(2) of the Directive, thus, set an objective limit to the freedom of religious organisations, i.e. effective judicial review of their decisions must be allowed.

The latter point might seem obvious to many readers of this journal, but from the viewpoint of German law, it was nothing short of a revolution: the Court of Justice broke the barriers that German law had erected to protect the autonomy of religious organisations from interference by state powers, including civil courts. Since the Egenberger and $I R \mathrm{v} J Q$ judgments, German civil courts may review not only the plausibility but also the substance of decisions of religious organisations when those decisions are alleged to discriminate against workers on the ground of religion or beliefs.

This, however, is only the first revolution that Egenberger and $I R \mathrm{v} J Q$ unleashed in Germany. The second revolution is perhaps even greater in scope, since it concerns the direct horizontal effect of (EU) fundamental rights.

\section{EGENBERgER, IR v JQ, AND THE DIRECT HORIZONTAL EFFECT OF Charter Rights}

A central question submitted for preliminary ruling in both Egenberger and $I R \mathrm{v}$ $J Q$ asked whether, if Article 4(2) of Directive 2000/78 cannot be interpreted from the abovementioned subjective perspective, a national court must disapply a provision of national law by which unequal treatment based on a worker's religious affiliation can be justified based on the self-perception of the religious community in question.

\footnotetext{
${ }^{13} I R$ v $J Q$, para. 61.
} 
In Egenberger, the Court answered this question in a series of steps. The Court began by referring to the principle enshrined in its previous case law according to which the requirement to interpret national law in conformity with EU law includes an obligation for national courts to change their established case law if need be. A national court cannot rightly maintain that it is unable to interpret a provision of national law in conformity with EU law merely because that provision has consistently been interpreted in a manner incompatible with EU law. ${ }^{14}$

Then, in considering the hypothetical scenario in which it is not possible for a national court to interpret the applicable national law in conformity with Article 4(2) of the Directive, the Court of Justice intervened in the debate on the horizontal effect of EU fundamental rights. ${ }^{15}$

Interestingly, as far as the direct horizontal effect of the prohibition of discrimination on grounds of religion was concerned, the Court's position diverged from the Opinion delivered by Advocate General Tanchev in Egenberger. The Advocate General had concluded that the prohibition of discrimination on grounds of religion should not create a subjective right capable of being applied horizontally in situations involving private parties. Instead, according to the Advocate General, the remedy available to the applicant under EU law was a state liability action seeking damages from Germany. ${ }^{16}$

The Court in Egenberger did not follow the Advocate General on this point. Instead, the Court acknowledged the direct effect of Article 47 of the Charter and

${ }^{14}$ Egenberger, paras. $71-73$ with references to $D I$.

${ }^{15} \mathrm{On}$ the horizontal effect of fundamental rights and principles in EU laws see inter alia A. Hartkamp, 'The Effect of the EC Treaty in Private Law: On Direct and Indirect Horizontal Effects of Primary Community Law', 3 European Review of Private Law (2010) p. 527; E. Spaventa, 'The Horizontal Application of Fundamental Rights as General Principles of Union Law', in A. Arnull et al. (eds.), A Constitutional Order of States - Essays in Honour of Alan Dashwood (Hart Publishing 2011) p. 199; D. Leczykiewicz, 'Horizontal Application of the Charter of Fundamental Rights', 38 European Law Review (2013) p. 479; C. Mak, 'Uncharte(re)d Territory: EU Fundamental Rights and National Private Law', CESCL Working Paper Series No. 2013-05, Amsterdam Law School Research Paper No. 2013-25; A. Colombi Ciacchi, 'European Fundamental Rights, Private Law and Judicial Governance', in H.-W. Micklitz (ed.), The Constitutionalisation of European Private Law (Oxford University Press 2014) p. 102; E. Frantziou, 'The Horizontal Effect of the Charter of Fundamental Rights of the EU: Rediscovering the Reasons for Horizontality', 21 European Law Journal (2015) p. 657; O. Cherednychenko and N. Reich, 'The Constitutionalization of European Private Law: Gateways, Constraints, and Challenges', 23 European Review of Private Law (2016) p. 797; E. Frantziou, The Horizontal Effect of Fundamental Rights in the European Union: A Constitutional Analysis (Oxford University Press 2019).

${ }^{16}$ Opinion of AG Tanchev in Case C-414/16 Egenberger, ECLI:EU:C:2017:851, para. 119. On this divergence between the AG's opinion and the Court's decision, see Lourenço, supra n. 9, p. 198-199. 
the direct horizontal effect of Article 21(1) of the Charter. ${ }^{17}$ The latter principle was then confirmed by $I R \mathrm{v} J Q{ }^{18}$

The Court considered Article 21(1) of the Charter 'sufficient in itself to confer on individuals a right which they may rely on as such in disputes between them in a field covered by EU law. ${ }^{19}$ In this regard, it clarified that '(a)s regards its mandatory effect, Article 21 of the Charter is no different, in principle, from the various provisions of the founding Treaties prohibiting discrimination on various grounds, even where the discrimination derives from contracts between individuals. ${ }^{20}$ Here the Court referred to its previous judgments in cases such as Defrenne and Angonese. In Defrenne, the Court explicitly stated that the prohibition of discrimination applied equally to all agreements intended to regulate paid labour collectively, 'as well as to contracts between individuals'. ${ }^{21}$ Furthermore, in Angonese, ${ }^{22}$ the private party that the Court considered bound by the Treaty's prohibition of discrimination was not a private regulator (such as a labour union) but a normal, private employer (a bank). Therefore, after Defrenne and Angonese, it should have been clear that the direct horizontal effect of EU fundamental rights and freedoms could apply to contracts between individuals.

Hence, from a purely EU law viewpoint, acknowledgement of the direct horizontal effect of Article 21 of the Charter in Egenberger was neither revolutionary nor surprising. Arguably, there is a logical and continuous line that extends from van Gend and Loos $^{23}$ to Egenberger, passing through Walrave, ${ }^{24}$ Defrenne, ${ }^{25}$ Angonese, ${ }^{26}$ Mangold, ${ }^{27}$ Küüudeveci, ${ }^{28}$ and $D I^{29}$ along the way. As a result, the

\footnotetext{
${ }^{17}$ For a comment on Egenberger from the viewpoint of the horizontal effect doctrines, see E. Frantziou, 'Mangold recast? The ECJ's flirtation with Drittwirkung in Egenberger', European Law Blog, 24 April 2018 (europeanlawblog.eu/2018/04/24/mangold-recast-the-ecjs-flirtationwith-drittwirkung-in-egenberger/ $\rangle$, visited 29 April 2019. See also A. Colombi Ciacchi, 'Egenberger and Comparative Law: A Victory of the Direct Horizontal Effect of Fundamental Rights', 5 European Journal of Comparative Law and Governance (2018) p. 207.

${ }^{18} I R$ v JQ, paras. 64-65 and 69, with reference to Egenberger.

${ }^{19}$ Egenberger para. 76 (emphasis added), with reference to Association de médiation sociale; $I R \mathrm{v}$ $J Q$, para. 69 with reference to Egenberger.

${ }^{20}$ Egenberger, para. 77.

${ }^{21}$ ECJ 8 April 1976, Case C-43/1975, Defrenne.

${ }^{22} \mathrm{ECJ} 6$ June 2000, Case C-281/98, Angonese.

${ }^{23}$ ECJ 5 February 1963, Case 26/62, van Gend \& Loos.

${ }^{24}$ ECJ 12 December 1974, Case C-36/1974, Walrave and Koch.

${ }^{25}$ Supra n. 21.

${ }^{26}$ Supra n. 22.

${ }^{27}$ ECJ 22 November 2005, Case C-144/04, Mangold.

${ }^{28}$ ECJ 19 January 2010, Case C-555/07, Kücükdeveci.

${ }^{29}$ ECJ 19 April 2016, Case C-441/14, Dansk Industri (DI).
} 
prohibition of discrimination as a general principle of EU law, now codified in Article 21 of the Charter, has direct horizontal effect in all fields covered by EU law. ${ }^{30}$

\section{THE SECOND REVOLUTION: THE COMEBACK OF THE DIRECT HORIZONTAL EFFECT OF FUNDAMENTAL RIGHTS IN GERMAN LABOUR LAW}

The revolutionary impact of Egenberger primarily concerns the cross-national debate on the direct and indirect horizontal effect of fundamental rights, with particular regard to German law. The origins of this debate go back to the aftermath of World War II when new democratic constitutions were being enacted in several continental European countries. In the late 1940s, the national courts of various EU member states, including Italy and Germany, started applying new constitutionally-protected fundamental rights and principles (such as the equality principle) directly when adjudicating litigation that involved labour relationships. ${ }^{31}$ In the 1970s, the Court of Justice also began to apply fundamental principles enshrined in the Treaty, such as the prohibition of discrimination, directly when adjudicating litigation that involved labour relationships. ${ }^{32}$ One could, therefore, argue that a harmonious judicial dialogue, ${ }^{33}$ or at least a harmonious judicial interaction, existed on this issue between the Court of Justice and the national courts of the said member states through the end of the 1970s. ${ }^{34}$

This state of harmony was partially interrupted in the 1980s by a change of prevalent opinion in Germany. In order to understand this change, one has to consider the history of the German judicial dialogue on the horizontal effect of fundamental rights on labour relationships. ${ }^{35}$ In the early 1950s, Germany was one of the first

\footnotetext{
${ }^{30}$ See Colombi Ciacchi, supra n. 17, p. 207-208.

${ }^{31}$ See the judgments referred by Colombi Ciacchi, supra n. 15, p. 113, fn. 56. On the direct and indirect horizontal application of fundamental rights to the adjudication of private litigation in nine European countries, see G. Brüggemeier et al. (eds.), Fundamental Rights and Private Law in the European Union. Volume 1: A Comparative Overview (Cambridge University Press 2010).

${ }^{32}$ Walrave, supra n. 24; Defrenne, supra n. 21. See Colombi Ciacchi, supra n. 15, p. 113-114. For a relatively recent account of the horizontal effect of EU fundamental rights, see M. Fornasier, 'The Impact of EU Fundamental Rights on Private Relationships: Direct or Indirect Effect?', 23 European Review of Private Law (2015) p. 29.

${ }^{33}$ On judicial dialogue, see F. Cafaggi and S. Law, 'Judicial dialogue in European private law: introductory remarks', in F. Cafaggi and S. Law (eds.), Judicial Cooperation in European Private Law (Edward Elgar 2017) p. 1 ff.

${ }^{34}$ This and the following paragraphs (i.e. the text between n. 29 and n. 44) constitute an updated and shortened version of section IV ('Angonese and the cross-national judicial dialogue on the horizontal effect of fundamental rights') of A. Colombi Ciacchi, 'European fundamental rights and private litigations: judicial dialogue and judicial governance', in Cafaggi and Law, supra n. 33, p. 208 ff.

${ }^{35}$ Colombi Ciacchi, supra n. 34, p. 216-218.
} 
European countries to embrace the doctrine of the direct horizontal effect, on labour relationships, of fundamental rights and constitutional principles. This doctrine was mainly developed by Nipperdey, who, in addition to being a scholar, ${ }^{36}$ was also President of the German Federal Labour Court (Bundesarbeitsgericht) from 1954 until 1963. Not unrelatedly, the first Bundesarbeitsgericht decision on the direct horizontal effect of fundamental rights was issued as early as $1954 .{ }^{37}$

However, in its famous Lüth decision of $1958,{ }^{38}$ the German Federal Constitutional Court (Bundesverfassungsgericht) did not follow Nipperdey's doctrine. Instead, it embraced the doctrine of the indirect horizontal effect of fundamental rights theorised by Dürig, one of the leading commentators on the German Constitution. ${ }^{39}$ Since the Lüth case did not concern labour law, the Bundesarbeitsgericht continued to apply the direct horizontal effect doctrine to labour relationships through the 1980s. The state of disharmony in the internal German judicial dialogue on this issue came to an end in 1985 when the Bundesarbeitsgericht aligned its jurisprudence with that of the Bundesverfassungsgericht and definitively rejected the direct horizontal effect doctrine with respect to individual labour relationships. ${ }^{40}$ Moreover, over the course of the last 30 years, the Bundesarbeitsgericht has increasingly established the indirect horizontal effect doctrine as far as collective labour agreements are concerned. ${ }^{41}$

The current German approach ${ }^{42}$ substantially converges with current opinion prevalent in the UK, which also supports giving merely indirect horizontal effect

${ }^{36}$ H.C. Nipperdey, 'Gleicher Lohn der Frau für gleiche Arbeit', Recht der Arbeit (1950) p. 121; H.C. Nipperdey, in L. Enneccerus and H.C. Nipperdey, Allgemeiner Teil des Bürgerlichen Rechts, $14^{\text {th }}$ edn (Mohr 1954); H.C. Nipperdey, 'Die Würde des Menschen', in K.A. Bettermann et al. (eds.), Die Grundrechte. Handbuch der Theorie und Praxis der Grundrechte Vol. II: Die Freiheitsrechte in Deutschland (Duncker \& Humblot 1954) p. 111, 143; H.C. Nipperdey, Grundrechte und Privatrecht (Scherpe 1961).

${ }^{37}$ BAG 3 December 1954, BAGE 1, 185; NJW 1955, 606. For a comment in English see P. Beckmann et al., 'Germany', in Brüggemeier et al., supra n. 31, p. 253, 289-90.

${ }^{38}$ BVerfG 15 January 1958, BVerfGE 7, 198. For a commentary in English, see G. Brüggemeier, 'Constitutionalisation of Private Law - The German Perspective', in T. Barkhuysen and S. Lindenbergh (eds), Constitutionalisation of Private Law (Brill/Nijhoff 2006) p. $59 \mathrm{ff}$.

${ }^{39} \mathrm{G}$. Dürig, 'Grundrechte und Zivilrechtsprechung', in T. Maunz (ed.), Vom Bonner Grundgesetz zur gesamtdeutschen Verfassung, Festschrift zum 75. Geburtstag von Hans Nawiasky (Beck 1956) p. 176.

${ }^{40}$ BAG 27 February 1985, BAGE 48, 123. For an overview of the scholarly debate on the direct and indirect horizontal effect of fundamental rights in labour relationships between 1950 and 1985 , see D. Fabisch, Die unmittelbare Wirkung der Grundrechte im Arbeitsrecht (Peter Lang 2010) p. 223.

${ }^{41}$ BAG 25 February 1998, BAGE 88, 118, 123; BAG 18 March 2009, BAGE 130, 43. See the comments to these judgments quoted in Colombi Ciacchi, supra n. 34, p. 218.

${ }^{42} \mathrm{On}$ the horizontal effect of fundamental rights and freedoms in Germany, see D. Looschelders and M. Makowsky, 'The Influence of Human Rights and Basic Rights in German Private Law', in V. Trstenjak and P. Weingerl (eds.), The Influence of Human Rights and Basic Rights in Private Law (Springer 2016) p. $295 \mathrm{ff}$, with further references. See also the other works quoted in Colombi Ciacchi, supra n. 34, p. 218. 
to fundamental human rights in contractual relationships. ${ }^{43}$ The German and UK approaches do, however, clash with the position of courts and scholars prevalent in other European countries such as Italy and France, where fundamental rights are undoubtedly deemed to have direct horizontal effect on labour relationships. ${ }^{44}$

As a result, Angonese, Mangold, Kücükdeveci, and now Egenberger and $I R \mathrm{v} J Q$, fully harmonise with the previous Court of Justice jurisprudence and ItalianFrench case law while clashing with the current approach in Germany and the UK. ${ }^{45}$

Although the judges who decided Angonese, Egenberger, and $I R \mathrm{v} J Q$ may have been unaware of the conflict of views between the judiciaries of different Member States regarding the direct application of fundamental rights and freedoms to labour relationships, the abovementioned decisions objectively represent, independent of the judges' subjective awareness, a strong voice in the supranational and cross-national judicial dialogue on the horizontal effect of fundamental rights, freedoms, and constitutional principles. ${ }^{46}$ Those judgments arguably mark the victory of the direct horizontal effect doctrine in fields covered by EU law, at least as far as labour relationships are concerned. ${ }^{47}$

For purposes of German law, Egenberger and $I R \mathrm{v} J Q$ could be seen as the comeback of the direct horizontal effect doctrine - a posthumous victory, so to say, of Nipperdey over Dürig. Those two judgments constitute a double revolution in the principles established by the German Federal Constitutional Court: they contradict both its stance on the direct horizontal effect of fundamental rights and its case law on the autonomy of religious organisations in employment matters. It remains to be seen whether the Federal Constitutional Court will accept the Court of Justice's approach, ${ }^{48}$ or whether a new Solange-like saga will unfold.

\footnotetext{
${ }^{43}$ For a comparison of the German and English horizontal effect approaches, see J.F. Krahé, 'The Impact of Public Law Norms on Private Law Relationships - Horizontal Effect in German, English, ECHR and EU Law', 2 European Journal of Comparative Law and Governance (2015) p. 124 with further references. See also the works quoted in Colombi Ciacchi, supra n. 34, p. 218.

${ }^{44}$ C. Herrmann and C. Perfumi, 'France', in Brüggemeier et al., supra n. 31, p. 190, 206 ff; C. Mak et al., 'Italy', ibid., p. 325, 341.

${ }^{45}$ See Colombi Ciacchi, supra n. 34, p. 219 and Colombi Ciacchi, supra n. 17, p. 211.

${ }^{46} \mathrm{Ibid}$.

${ }^{47}$ Colombi Ciacchi, supra n. 17, p. 211.

${ }^{48}$ See P. Stein, 'Der Fall Egenberger und das kirchliche Arbeitsrecht', Humanistische Union, 22 November 2018, (www.humanistische-union.de/nc/aktuelles/aktuelles_detail/back/aktuelles/ article/der-fall-egenberger-und-das-kirchliche-arbeitsrecht/ $\rangle$, visited 29 April 2019: the Bundesverfassungsgericht will ultimately have to decide whether to accept the correction from Luxembourg or, instead, to find a violation of the identity of the German Constitution.
} 


\section{ConClusion}

The Egenberger and $I R \mathrm{v} J Q$ decisions are two wonderful pieces of $\mathrm{EU}$ constitutional law. They contain several courageous statements that consolidate and enhance the constitutionalisation of not only European private law ${ }^{49}$ but also EU law in general.

On the one hand, these decisions have confirmed and reinforced well-known case law principles on the direct horizontal effect of the prohibition of discrimination in labour relationships which have evolved in a coherent line that started with Defrenne and continued on through Mangold, Kücükdeveci, and DI. On the other hand, however, Egenberger and $I R \mathrm{v} J Q$ went beyond those rulings in at least three regards. First, they clearly acknowledged the direct horizontal effect of at least certain Charter rights. Second, Egenberger 'unequivocally proclaims Article 47 of the Charter on effective judicial protection as a fully-fledged right ${ }^{50}$ with direct effect in the adjudication of private litigation. Third, Egenberger clarified the compatibility of the direct (horizontal) effect of Articles 21 and 47 of the Charter with the obligation of national courts to balance competing fundamental rights.

Ultimately, although Egenberger and $I R \mathrm{v} J Q$ have limited the autonomy of religious organisations to some extent, they did not interfere with the freedom of national courts to balance competing fundamental rights according to national constitutional values. As Frantziou correctly noted, Egenberger offers a methodology for assessing the application of fundamental rights in disputes between private parties that is capable of reconciling the effectiveness of EU law with national constitutional structures. It (...) marks a more discursive form of constitutional reasoning than the Court has previously used in this field'. ${ }^{51}$

\footnotetext{
${ }^{49}$ On this phenomenon, see the collection of essays in Micklitz, supra n. 15.

${ }^{50}$ Lourenço, supra n. 9, p. 200.

${ }^{51}$ Frantziou, supra n. 17.
} 